\title{
Properties evaluation of semi-crystalline and amorphous polymers injected in AISI P20 molds repaired by welding
}

Rafael Junkes ${ }^{1}$, Janaina Lisi Leite Howarth ${ }^{1}$, Daniela Becker ${ }^{2}$, Danielle Bond ${ }^{2}$

\author{
${ }^{1}$ Centro Universitário Sociesc/UNISOCIESC, Albano Schmidt, 3333, Joinville, Santa Catarina, SC, Brasil. \\ ${ }^{2}$ Universidade do Estado de Santa Catarina/UDESC - Centro de Ciências Tecnológicas, Paulo Malschitzki, 200, Joinvil- \\ le, Santa Catarina, SC, Brasil. \\ e-mail: rafaj.mestrado@gmail.com, janaina.leite@unisociesc.com.br, daniela.becker@udesc.br, danielle.bond@udesc.br
}

\begin{abstract}
Injection molds can fail after a certain period of use, which may compromise the final part's integrity and quality, but that can be solved using welding repair processes. This work aimed to investigate the influence of AISI P20 molds repaired by Gas Tungsten Arc Welding (GTAW) and Nd-YAG laser-welding processes on the properties of injection-molded parts with semi-crystalline (polypropylene) and amorphous (polycarbonate and acrylonitrile butadiene and styrene terpolymer) thermoplastics. Welds were prepared by machining $0.8 \mathrm{~mm}$-deep $40 \mathrm{~mm}$ x $5 \mathrm{~mm}$ grooves to be filled by GTAW and Nd-YAG laser-welding deposits, in order to simulate the repair of AISI P20 molds. All polymers were injected into weld-repaired and unrepaired molds, and then evaluated in terms of microstructure, crystallinity degree, mechanical properties and gloss. The results suggest that the repaired region for both studied welding processes, despite the difference in hardness of the weld region, does not significantly affect the properties of semi-crystalline and amorphous injected polymers.
\end{abstract}

Keywords: molds, weld repair, polymers, injected parts, AISI P20.

\section{INTRODUCTION}

Injection molding is one of the most prominent polymer processing techniques due to its versatility and high productivity, enabling large numbers of parts with varying geometry and excellent dimensional tolerance to be produced at low cost $[1,2,3,4]$. During injection, the polymeric material goes through several changes due to variations in the thermomechanical environment by which it is restricted. The environment, characterized by heating and cooling rates and different stress fields, causes an intrinsic heterogeneous microstructure in the molded parts, characterized by a gradual variation in morphology, crystallinity, molecular orientation and, consequently, final properties. Such variations are associated with processing conditions, mold geometry and polymer properties $[5,6]$.

According to MATEO et al. [7], KOVÁCS and SIKLÓ [8], the mold surface finish quality is an essential requirement due to its direct effects on the appearance or frictional characteristics on the sliding surfaces of the final plastic product. Another important aspect during injection molding is heat transfer between polymer and cavity wall, because it significantly affects temperature distribution to the parts and alters temperature distribution in the mold, consequently affecting mechanical behavior, microstructure and dimensional precision of the injected parts, as well as production efficiency [4]. A non-uniform cooling rate can cause a differential shrinkage, resulting in warpage and distortion in the injected parts [8].

A mold that has not been correctly designed in terms of geometry, manufacture material and injected polymer, as well as a mold with defects and flaws caused by usage wear, may compromise the final part's integrity and quality [4, 9]. In the production of automotive components, $80 \%$ of all molds undergo a repair/remanufacture process at some point. Industrial companies normally prefer to machine the damaged layer of stamping and hot forging dies to regain the dimensional tolerance of die cavities. However, the disadvantage of such method is that the mass and structure of dies are constantly reduced after each repair and the potential consequences are yet to be revealed [9].

Those issues can also be solved with cold spray, but it is usually accomplished using welding processes, such as: Plasma Transferred Arc Welding (PTAW); Micro-GTAW and Micro-Plasma; Electron Beam Welding (EBW) and Electro-Spark Welding; and Plasma Arc Welding (PAW). However, traditionally, the main repair process has been Gas Tungsten 
Arc Welding (GTAW), and a new, non-traditional process is emerging, called Laser Based Material Deposition [10, 11, 12, 13]. An experimental methodology design to study the relationship between the Nd:YAG laser process parameters and welding profiles using sequential experimental design and artificial neural networks was proposed by [14].

The AISI P20 steel is the most widely used material in the injection molding industry, although with severe problems when recovered by welding. High-strength tool steels are very susceptible to hydrogen cracking due to the presence of martensitic structures after welding. To avoid such cracks, a preheating is usually performed to slow the cooling rate and avoid martensitic structures and/or eliminate the retained hydrogen. In multipass welding, during which several thermal cycles occur, the martensitic regions can be tempered, preventing cracking by hydrogen, but the hardness in the weld regions will be different from that of the base material [15]. The difference in hardness levels between the weld regions, however, may influence the behavior of the finishing processes for the injection mold cavity [16]. The polishing and mirroring processes depend on the hardness of the material and the surface texture uniformity depends on the region's chemical composition and microstructure [17]. Thus, the influence of welding parameters is very important for the metallurgical behavior of AISI P20.

Several papers have also been published on fundamental issues about welding procedures for repairing plastic-injection molds. However, those papers, published for sheet welding (single-pass welds) of tool steels, do not contemplate mold-specific requirements. Furthermore, after a thorough literature search, it appears that a deep knowledge about the influence of mold repair on the properties of injection-molded parts is not fully achieved. A contribution against such lack of literature data is given by the present paper.

In this context, the main goal of this paper is to investigate the influence of AISI P20 mold properties repaired by GTAW and Nd-YAG laser-welding on the properties of injection-molded parts with semi-crystalline (polypropylene) and amorphous (polycarbonate and acrylonitrile butadiene and styrene terpolymer) thermoplastics.

\section{EXPERIMENTAL PROCEDURE}

\subsection{Mold Manufacture and Weld Repair}

In order to achieve the proposed objectives, welds were prepared by machining $0.8 \mathrm{~mm}$-deep $40 \mathrm{~mm}$ x $5 \mathrm{~mm}$ grooves to be filled by GTAW and Nd-YAG laser-welding deposits, in order to simulate the repair of damaged tool surfaces. Welds were made in grooves on the lower part of a test specimens mold for tensile strength test in accordance to ISO 527-2, Figure 1.

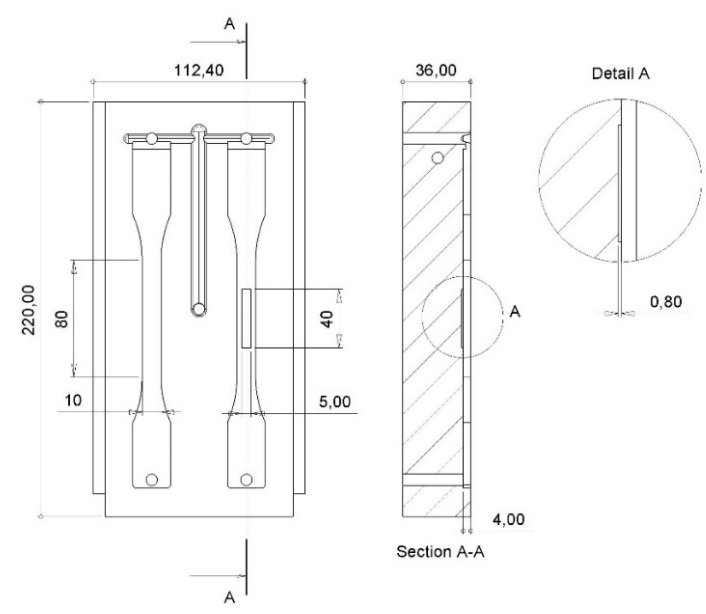

Figure 1: The lower mold with groove in order to simulate the repair of damaged tool surface (detail A). 
The following factors were kept constant in the welding tests (Table 1).

Table 1: Process conditions used for GTAW and Nd-YAG laser process.

\begin{tabular}{l|c|c}
\hline & GTAW $^{*}$ & ND-YAG LASER \\
\hline Shielding gas & Argonium $121 / \mathrm{min}$ & Argonium 12 1/min \\
\hline Filler wire & AWS $5.18 \mathrm{ER} 70 \mathrm{S3}$ & AWS 5.18 ER 70 S6 \\
\hline Wire diameter & $1,6 \mathrm{~mm}$ & - \\
\hline Nozzle diameter & $10 \mathrm{~mm}$ & - \\
\hline & $\mathrm{W}+2 \% \mathrm{ThO}$ & - \\
\hline Electrode & Diameter $2,4 \mathrm{~mm}$ & - \\
\hline & $60^{\circ}$ tip angle & - \\
\hline Current & $85 \mathrm{~A}$ & $8,5 \mathrm{~Hz}$ \\
\hline Pulse frequency & - & $4,5 \mathrm{~ms}$ \\
\hline Pulse duration & - & $1,0 \mathrm{~mm}$ \\
\hline Spot Diameter & - & $-* *$ \\
\hline Preheating temperature & $225^{\circ} \mathrm{C}\left( \pm 25^{\circ} \mathrm{C}\right)$ & - \\
\hline
\end{tabular}

*All the welds were done with constant value DC current.** Following usual industrial practice.

The used base materials were AISI P20 steels, which are Cr-Ni-Mo steels, known as low-alloy tool steels. The AISI P20 is a hardenable steel frequently used in the manufacturing of polymer injection molds. It is provided in the quenched and tempered state, with hardness between 30 and 34 HRC. By analyzing the chemical composition of the AISI P20 steel $($ CEiiw $=1.13 \%>0.4 \%)$, a preheating is recommended to minimize the martensite formation and reduce the risk of cracking during welding, using a filler metal with lower $\mathrm{C}$ and CEiiw than of the base metal is also suggested [15]. The base and filler materials' chemical compositions are shown in Table 2. The mechanical properties of both filler metals are similar according to AWS 5.18 ER 70 S3 and AWS 5.18 ER 70 S6 standards.

Table 2: Chemical composition of the base and filler metals (wt.\%), and their respective calculated CEiiw.

\begin{tabular}{|c|c|c|c|}
\hline ELEMENT & AISI P20a (\%) & $\begin{array}{c}\text { GTAW } \\
\text { AWS 5.18 ER 70S3 }{ }^{\mathrm{b}}(\%)\end{array}$ & $\begin{array}{c}\text { ND-YAG LASER } \\
\text { AWS 5.18 ER 70S6c (\%) }\end{array}$ \\
\hline Carbon & 0.422 & $0.06-0.15$ & $0.06-0.15$ \\
\hline Silicon & 0.455 & $0.45-0.75$ & $0.8-1.15$ \\
\hline Manganese & 1.54 & $0.9-1.4$ & $1.4-1.8$ \\
\hline Phosphor & 0.018 & 0.025 & 0.025 \\
\hline Sulphur & 0.004 & 0.035 & 0.035 \\
\hline Chromium & 1.86 & 0.15 & 0.15 \\
\hline Nickel & 0.70 & 0.15 & 0.15 \\
\hline Molybdenum & 0.198 & 0.15 & 0.15 \\
\hline Aluminum & 0.03 & & \\
\hline Copper & 0.121 & 0.5 & 0.5 \\
\hline Cobalt & 0.019 & & \\
\hline Titanium & 0.006 & & \\
\hline Vanadium & 0.015 & 0.03 & 0.03 \\
\hline Tungsten & 0.011 & & \\
\hline Tin & 0.014 & & \\
\hline Arsenic & 0.003 & & \\
\hline Ceiiw $^{\mathrm{c}}$ & 1.13 & 0.39 & 0.46 \\
\hline
\end{tabular}

${ }^{\mathrm{a}}$ Compositions measured by optical spectrometry. ${ }^{\mathrm{b}}$ Compositions provided by the manufacturer in products' quality certificates. ${ }^{\mathrm{c}}$ IIW carbon equivalent, $\mathrm{CEiiw}=\% \mathrm{C}+\% \mathrm{Mn} / 6+\%(\mathrm{Cr}+\mathrm{Mo}+\mathrm{V}) / 5+\%(\mathrm{Ni}+\mathrm{Cu}) / 15$. 
After the conclusion of the GTAW and Nd-YAG laser deposit welding operations, the mold surface was sanded (to remove the weld reinforcement and to reduce the roughness) and polished, aiming at obtaining the original geometry.

Weld beads were also made on a $200 \mathrm{~mm}$ x $50 \mathrm{~mm}$ x $32 \mathrm{~mm}$ AISI P20 steel plate using the same process conditions as those for the GTAW and laser processes, in order to evaluate the weld metal (WM), heat-affected zone (HAZ) and base metal (BM). After welding, the plates were sectioned, and hardness profiles were generated in a transverse direction to the welds using a Vickers microhardness tester in accordance to ASTM 384-08.

\subsection{Injection Molding Using Weld-Repaired and Unrepaired Molds}

The materials used for parts injection in the weld-repaired and unrepaired molds were polypropylene (PP) HP-550R (Quattor), polycarbonate (PC) HFVR1900 (Durolon) and acrylonitrile butadiene and styrene terpolymer (ABS)Terluran-GP22-Natural (Basf). Polymers PC and ABS were dried in an oven at $80^{\circ} \mathrm{C}$ for five hours. The injection machine was a Sandreto Micro 65 with a clamping force of 65 ton. Table 3 shows the injection process parameters for the injection molding for all polymers.

Table 3: Injection process parameters for polymers.

\begin{tabular}{l|c|c|c}
\hline PARAMETER & PP & ABS & PC \\
\hline Injection Pressure (bar) & 520 & 720 & 800 \\
\hline Holding Pressure (bar) & 400 & 480 & 640 \\
\hline Holding time $(\mathrm{s})$ & 9 & 6 & 7 \\
\hline Cooling time $(\mathrm{s})$ & 23 & 27 & 39.3 \\
\hline Cycle time $(\mathrm{s})$ & 41.5 & 44.6 & 75 \\
\hline Flow rate $\left(\mathrm{cm}^{3} / \mathrm{s}\right)$ & 68 & 70 & - \\
\hline Cooling water temperature $\left({ }^{\circ} \mathrm{C}\right)$ & 35 & - & 80 \\
\hline Oil temperature $\left({ }^{\circ} \mathrm{C}\right)$ & - & 80 & Zone $1=255$ \\
\hline Cylinder temperature $\left({ }^{\circ} \mathrm{C}\right)$ & Zone $1=218$ & Zone $1=220$ & Zone $2=245$ \\
\cline { 2 - 4 } & Zone $2=200$ & Zone $2=205$ & Zone $3=230$ \\
\cline { 2 - 4 } & Zone $3=195$ & Zone $3=195$ & Nozzle $=273$ \\
\cline { 2 - 4 } & Nozzle $=228$ & Nozzle $=231$ & \\
\hline
\end{tabular}

\subsection{Characterization of the Injection-Molded Parts}

The influence of weld-repaired molds on the crystallinity degree of the injected PP parts was determined using a TA Instruments Q20 differential scanning calorimeter. The experiments were carried out in a temperature ranging from $25^{\circ} \mathrm{C}$ to 300 ${ }^{\circ} \mathrm{C}$, with a heating rate of $10^{\circ} \mathrm{C}$.min- 1 . The calculation method considers the energy to melt all PP crystalline structures. Once this energy is known or estimated, a simple equation gives the degree of crystallization of the semi-crystalline polymer (Eq. 1).

$$
\% C=\left[\frac{\Delta H f a}{\Delta H f 100 \%}\right] \cdot 100
$$

Where $\% \mathrm{C}$ is the crystallinity degree (in percentage); $\Delta \mathrm{Hfa}$ is the sample's enthalpy of fusion; and $\Delta \mathrm{Hf} 100 \%=209 \mathrm{~kJ}$. $\mathrm{kg}-1$ is the enthalpy of fusion of fully crystalline PP [18]. The specimens were always obtained from the same place from the sample as shown in Figure 2. 

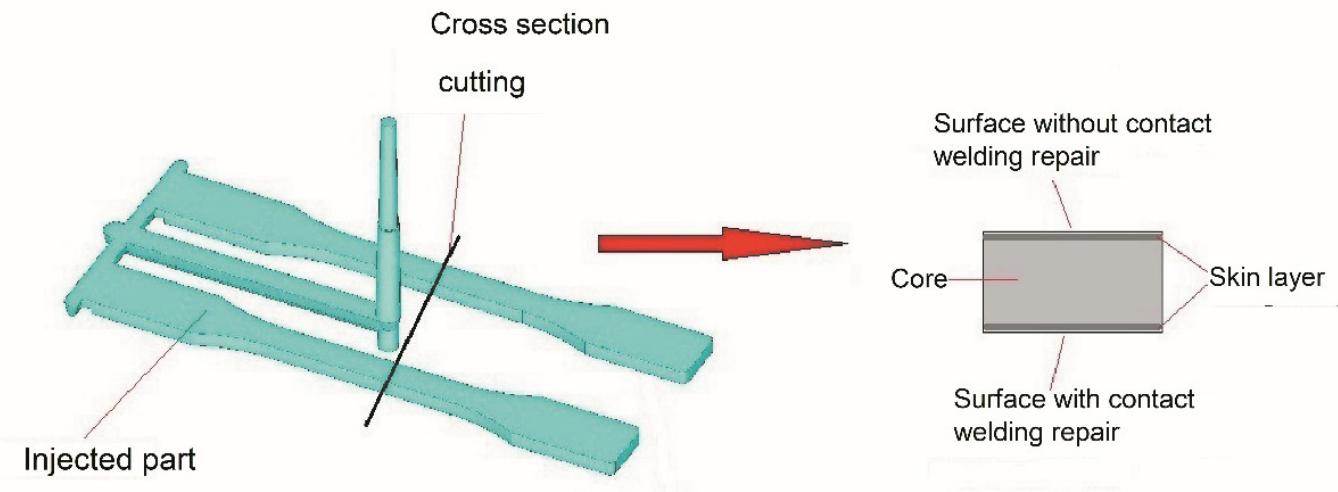

Figure 2: Sample location for measurement of crystallinity degree and microstructural characterization.

The morphological characterization of the injected PP parts was accomplished by polarized-light microscopy (PLM). The analyses were performed on thin specimens $(10 \mu \mathrm{m})$ that were microtomed with a Leitz 1401 microtome at room temperature. The observation was made with a polarized light microscope Olympus BH-2. The specimens were obtained as previously seen in Figure 2. Three specimens were obtained from each injected part in each condition (with cavities repaired by GTAW, laser and without repair).

The mechanical characterization of the injected parts from different polymers in weld-repaired and unrepaired molds was carried out by tensile and hardness shore tests. The tensile tests, according to the ISO 527-2 standard, were performed using a $500 \mathrm{~N}$ load cell with a $50 \mathrm{~mm} / \mathrm{min}$ crosshead rate at room temperature, using EMIC DL 3000 equipment. The Shore $\mathrm{D}$ hardness tests were performed on the surface of the injected parts according to the ISO 868 standard, using a $5 \mathrm{~kg}$ load and test time of $15 \mathrm{~s}$.

To evaluate the influence of weld-repaired molds on the surface gloss of injected parts, a gloss measurement was carried out. The variation of gloss was measured with a Espectro-guide 45/0 spectrophotometer (BYK-GARDNER) using a CIELab measurement system, under condition illumination/observer CIE D65/10 ${ }^{\circ}$. Three measurements were performed in three parts of each weld repair condition. All results are expressed as gloss units, relative to a highly polished surface of standard black glass with a value near 100 .

\section{RESULTS AND DISCUSSION}

\subsection{Microhardness of single-pass welds}

Microhardness measurements on transversal cross-sections of the welds are presented in Figure 3, which reveal the different steps corresponding to WM, HAZ and BM, respectively, of the GTAW and Nd-YAG laser single-pass welds.

Microhardness evolution was measured along vertical lines starting from the top surface of the deposit and moving across the weld metal zone toward the heat-affected zone and the basic metal. The average hardness measured in the WM, HAZ and BM regions were observed to be different. The large hardness difference between the WM, the HAZ and the BM was also observed by $[17,19,20,21,22]$. That happens because the WM and the HAZ regions result in a martensitic hard microstructure after welding, differently from the base material, which remains quenched and in tempered condition (supplied state) with a lower hardness. In Table 2, the filler metal used to weld the P20 steel can be observed to have C and CEiiw lower than that of the BM. This reduces hardening, like the preheating around the weld, but not enough to reach the same hardness as the base material [17]. 


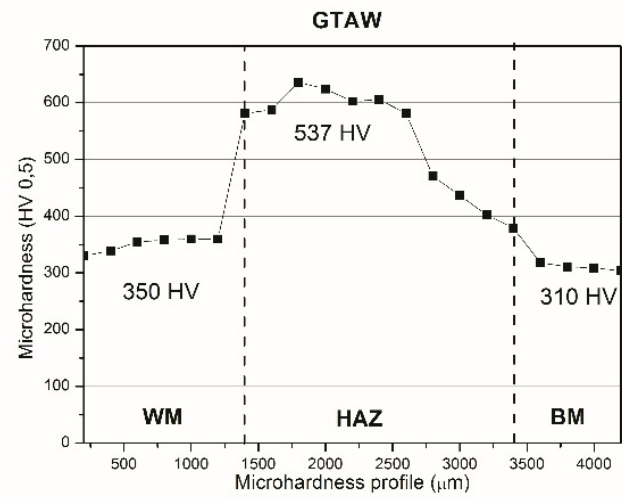

(a)

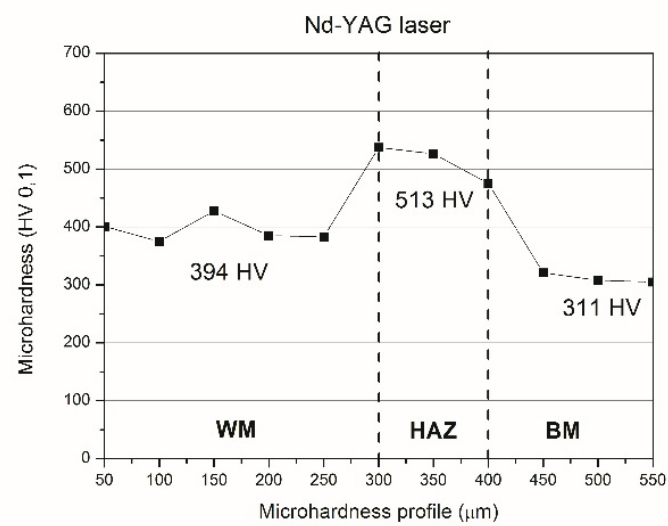

(b)

Figure 3: Distribution of hardness in the cross-section of the a) GTAW and b) Nd-YAG laser welds.

In multi-pass welds, overlapped regions were tempered by repeated welding thermal cycles, lowering values. However, this procedure did not lower the hardness to base metal values [20, 21, 23, 24]. Post-weld heat treatment can also be used after welding to temper, reducing residual weld stresses and removing hydrogen from the WM and HAZ [15]. However, any welding procedure which does not require post-weld heat treatment has significant cost and time advantages.

\subsection{Characterization of injected parts}

The crystallinity degree and morphology of the PP injected parts obtained in weld-repaired and unrepaired molds are presented in Table 4 and Figures 4 and 5, respectively. There was no significant difference in PP crystallinity degree under all conditions (Table 4). The largest difference was $4.0 \%$ for parts injected into the laser-welding-repaired mold. WANDER et al. [25] consider the difference of $5.17 \%$ in the crystallinity degree of molded parts with different cooling systems negligible. Similarly, TREML et al. [26] consider a difference of $7.5 \%$ in the crystallinity degree obtained in their study negligible.

The results suggest that both welding processes were well performed since no cracks were observed and the hardness difference between the weld regions did not result in a relevant variantion in the weld-repaired mold thermal properties.

Table 4: Crystallinity degree of the injected PP parts in the weld-repaired and unrepaired molds.

\begin{tabular}{c|c|c|c}
\hline CRYSTALLINITY DEGREE & UNREPAIRED & LASER WELD & GTAW WELD \\
\hline$\%$ & $34 \pm 2.5$ & $30 \pm 3.0$ & $32 \pm 5.0$ \\
\hline
\end{tabular}

The microstructural analysis performed by polarized-light microscopy (PLM), shown in Figure 4, aimed at the qualitative identification of the parts along the structure's thickness, and Figure 5 presents surface layer thickness. It is clear that, under the three studied conditions, the typical PP microstructure, composed of two skin layers (non-spherulitic) and a core (spherulitc), was developed [26,27]. The spherulite size gradually decreases from the core to the skin layer in the molded parts. This relates to temperature gradients arising in parts during solidification. According to CERMÁK et al. [26] and MARTINHO et al. [28], such gradients reflect the difference between the melting and the mold temperatures and, consequently, they are more pronounced at lower mold temperatures. The skin layers correspond to the surfaces in contact between the injected molten polymer and the mold, which is highly sheared and fast cooled. The skin layer is affected by the mold temperature, being thinner where the mold temperature is higher. This relates to the partial relaxation of oriented chains during solidification. Symmetry is also observed between the skin layers for all injected parts, with a refined spherulitic structure on the walls and coarser spherulitic structure in the core. In addition to similar morphological characteristics, Figure 5 shows similar skin thicknesses of PP molded parts under all conditions. Authors TREML [26], MARTINHO et al. [28] and BARETA et al. [29], who evaluated similar skin layer morphology for PP injected in molds manufactured from different materials, pointed out that the PP morphology undergoes variations such as thermal diffusivity conditions of the mold used in the injection process, which suggests the absense of any significant temperature distribution difference in the mold at the repair region, resulting in a similar heat flow between the molten polymer and the cavity under all conditions. 

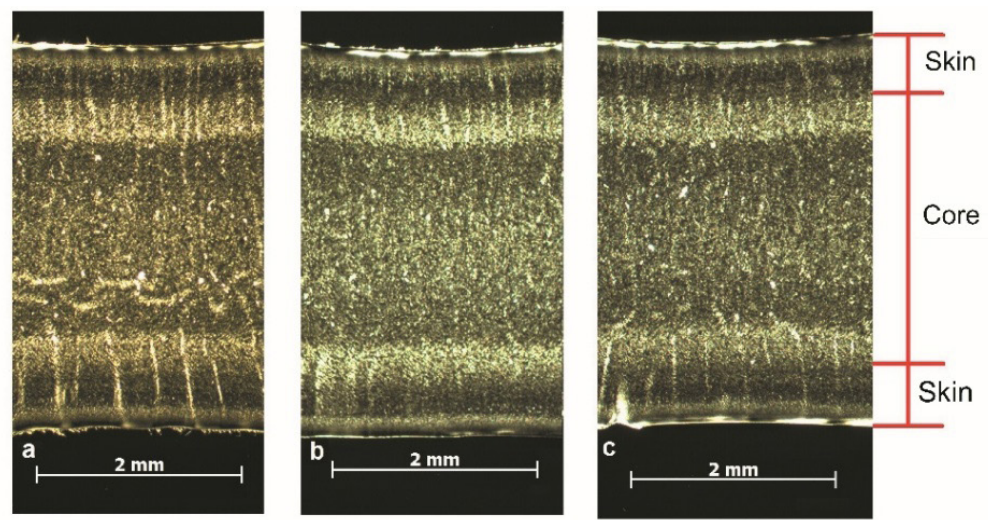

Surface in contact with the repair

Figure 4: Morphology of the cross-sections of injected PP parts into the mold: (a) unrepaired, (b) laser weld (c) GTAW weld.

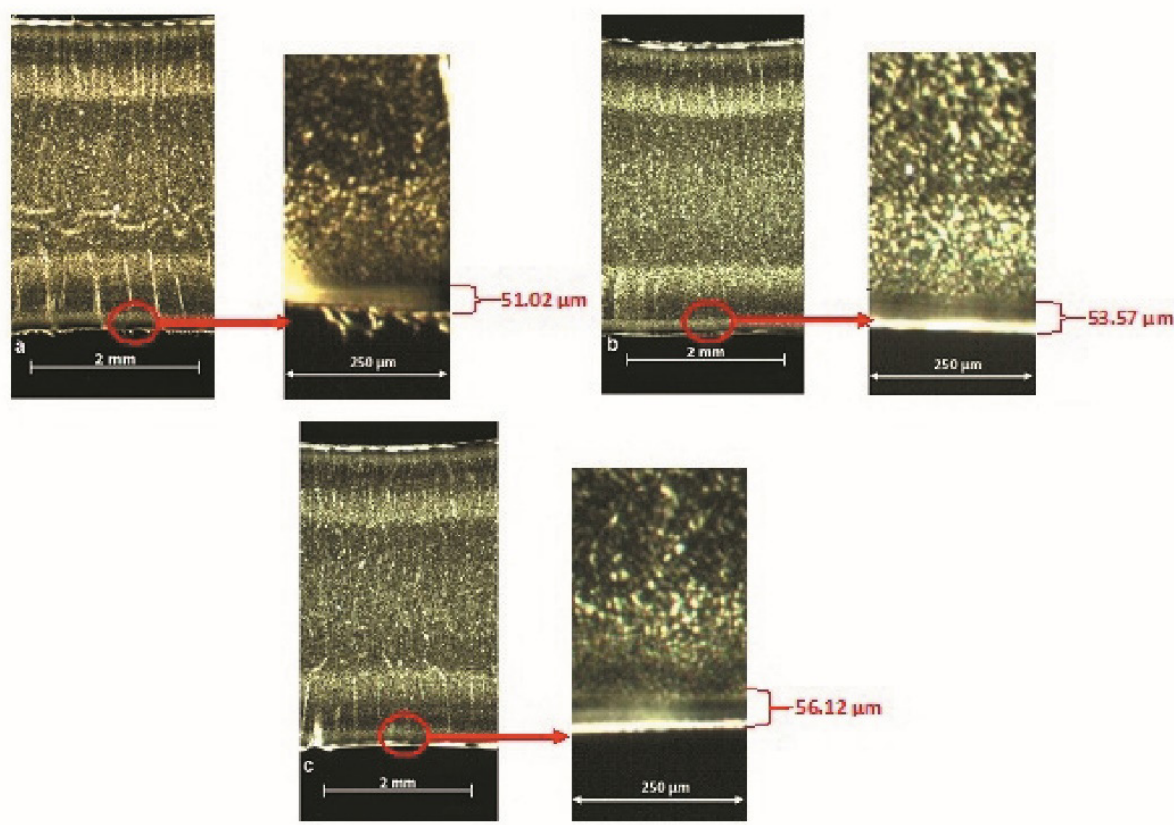

Figure 5: Surface layer thickness of injected PP parts into molds: (a) unrepaired, (b) laser weld and (c) GTAW weld.

The data in Table 5 show the mechanical properties of injected PP, ABS and PC parts in weld-repaired and unrepaired molds. As expected, the injected PP's mechanical properties under all conditions did not show any significant difference. Mechanical properties for semi-crystalline polymers are known to depend on their crystallinity characteristics, such as crystallinity degree and morphological structure. Properties such as impact and tensile strength, thermal stability and optical characteristics are influenced by the crystallinity degree, the crystallite structure distribution and the crystal structure, however all those properties strongly depend on crystallization kinetics. According to references from RIZVI et al. [30] and JIANG et al. [31], the temperature gradient between the melt and the mold (high conductivity) highly influences the cooling rate, which is the factor primarily governing the crystallization and, hence, the mechanical strength. The thermal conductivity controls the rate of heat transfer within the polymer, and the heat transfer coefficient controls the heat transfer at the interface between the polymer and the mold wall [32]. A higher mold temperature, normally above Tg for semi-crystalline polymers, tends to reduce the thickness of the skin layer and increase the relative crystallinity. In this work, the PP injected parts' crystallinity degree and morphology results were not influenced by the weld-repaired and unrepaired molds, suggesting that the weld-repaired molds did not significantly change the thermal conductivity, which would, consequently, have affected the injected parts' cooling rate and their morphological structure. This also corroborates the mechanical properties results, because the mechanical properties depend on the polymer's crystalline structure, which, in turn, is greatly influenced by the melt cooling rate inside the mold.

For amorphous polymers, a rapid and inhomogeneous cooling causes thermal stresses, which are responsible for 
permanent molecular orientation and can compromise the polymers' mechanical properties performance [33]. ABS and PC mechanical properties do not show any significant difference between the results for weld-repaired and unrepaired molds injected parts either. Such behavior indicates the absence of any temperature distribution changes inside molds repaired under different conditions strong enough to alter the mechanical properties for semi-crystalline or amorphous polymers.

Table 5: Mechanical properties of injected parts into weld-repaired and unrepaired molds.

\begin{tabular}{|c|c|c|c|c|}
\hline PROPERTY & POLYMER & LASER WELD & GTAW WELD & NO WELD \\
\hline \multirow{3}{*}{$\begin{array}{l}\text { Ultimate Tensile Strenght } \\
\text { (MPa) }\end{array}$} & $\mathrm{PP}$ & $32.0 \pm 1.1$ & $32.0 \pm 1.0$ & $31.7 \pm 1.2$ \\
\hline & ABS & $41.0 \pm 1.0$ & $41.0 \pm 0.6$ & $40.5 \pm 1.2$ \\
\hline & $\mathrm{PC}$ & $60.4 \pm 0.8$ & $60.4 \pm 0.8$ & $60.0 \pm 0.8$ \\
\hline \multirow{3}{*}{ Elastic Modulus (MPa) } & $\mathrm{PP}$ & $837.6 \pm 154$ & $790.2 \pm 155$ & $795.0 \pm 71.0$ \\
\hline & ABS & $1,284 \pm 218$ & $1,261 \pm 202$ & $1.190 \pm 107$ \\
\hline & $\mathrm{PC}$ & $1,318 \pm 153$ & $1,331 \pm 156$ & $1.379 \pm 183$ \\
\hline \multirow{3}{*}{ Shore D Hardness } & PP & $65.6 \pm 0.8$ & $65.3 \pm 1.0$ & $64.4 \pm 0.5$ \\
\hline & ABS & $71.3 \pm 0.7$ & $71.2 \pm 0.5$ & $70.1 \pm 2.3$ \\
\hline & $\mathrm{PC}$ & $78.7 \pm 3.0$ & $79.0 \pm 0.6$ & $76.2 \pm 1.4$ \\
\hline
\end{tabular}

The ABS and PC gloss is due to the cavity's surface finish and the even distribution of mold temperature [30]. There are three common finishing processes: polishing, mirroring and texturing. PRECIADO and BOHORQUEZ [17] pointed out that the large hardness difference between the WM, the HAZ and the BM makes polishing and mirroring difficult. The large hardness difference makes the use of more rigid polishing cloths necessary, in order to maintain their form and allow a uniform removal in the weld and BM regions. On the other hand, according to the authors, the hardness difference did not affect the Rz roughness of the texturized surfaces. The textured surfaces were not uniform, with a deeper chemical attack in the BM, because it is under the quenched and tempered condition. They suggest that the answer to the chemical attack depends on the form in which the alloy elements are presented (in solid solution or as part of precipitates).

Analyzing the gloss results (Table 6), it is apparent that small deviations from the average are not statistically significant, which suggests that the repair region, despite the difference in hardness observed in Figure 3, does not significantly affect the surface finish or the mold temperature distribution. According to PÖSTCH and MICHAELI [1], crystallinity influences optical properties of PP (semi-crystalline polymer) such as gloss and opacity. Therefore, such low injected part gloss variation corroborates the degree of crystallinity result, which did not show any significant changes.

Table 6: Average gloss values and standard deviation of injected PP, ABS and PC parts into molds: (a) unrepaired, (b) Nd-YAG laser weld and (c) GTAW weld.

\begin{tabular}{c|c|c|c|c}
\hline \multicolumn{2}{c|}{} & LASER WELD & GTAW WELD & NO WELD \\
\hline \multirow{3}{*}{ Gloss (\%) } & PP & $43.1 \pm 4.6$ & $43.0 \pm 6.0$ & $42.5 \pm 1.2$ \\
\cline { 2 - 5 } & ABS & $51.1 \pm 2.8$ & $49.8 \pm 3.2$ & $49.2 \pm 4.5$ \\
\cline { 2 - 5 } & PC & $84.0 \pm 2.3$ & $87.0 \pm 4.8$ & $86.6 \pm 4.0$ \\
\hline
\end{tabular}

\section{CONCLUSIONS}

The average hardness values measured in the WM, HAZ and MB regions in AISI P20 were different between GTAW and Nd-YAG laser single-pass welds. The same behavior was expected for multi-pass welds as used in the molds.

Under all three studied conditions (unrepaired, GTAW and Nd-YAG laser-repaired molds), the semi-crystalline polymer (PP) presented a typical microstructure composed of two skin layers (non-spherulitic) with a core (spherulitc), with the same thickness and crystallinity degree. Therefore, the injected PP showed no significant difference in mechanical properties and gloss, as well as the amorphous polymers (ABS and PC).

Thus, the repair region for both studied welding processes, despite the difference in hardness, does not significantly affect the properties of injected semi-crystalline or amorphous polymers. 


\section{ACKNOWLEDGEMENTS}

The authors would like to thank the Polymer Engineering Department of Minho University/Portugal for the polarized-light microscopy (PLM) analysis; the Molds and Dies Schuma Company for the cutting tools for molds machining and Special Welds Armênio for the laser and TIG welds.

\section{BIBLIOGRAPHY}

[1] PÖSTCH, G., MICHAELI, W., "Introduction”, Injection Molding, chapter 1, New York, USA, Hanser Gardner Publications, 1995.

[2] YANG, Y., GAO, F., “Adaptive Control of Injection Velocity of Thermoplastic Injection Molding”, Control Engineering Practice, v. 8, pp. 1285-1296, Jul. 1999.

[3] FOLGADO, R., PEÇAS, P., HENRIQUES, E., "Life cycle cost for technology selection: A Case study in the manufacturing of injection moulds", International Journal of Production Economics, v. 128, n. 1, pp. 368-378, Nov. 2010.

[4] LIU, Y., GEHDE, M., "Evaluation of heat transfer coefficient between polymer and cavity wall for improving cooling and crystallinity results in injection molding simulation", Applied Thermal Engineering, v. 80, pp. 238-246, Apr. 2015.

[5] VIANA, J.C., CUNHA, A.M., BILLON, N., "The thermo mechanical environment and the microstructure of an injection moulded polypropylene copolymer”, Polymer, v. 43, n. 15, pp. 4185-4196, Jul. 2002.

[6] ZHU, P.W., EDWARD, G., "Morphological distribution of injection-moulded isotactic polypropylene: a study of synchrotron small angle X-ray scattering”, Polymer, v. 45, n. 8, pp. 2603-2613, Apr. 2004.

[7] MARTÍNEZ-MATEO, I., CARRIÓN-VILCHES, F.J., SANES, J., et al., "Surface damage of mold steel and its influence on surface roughness of injection molded plastic parts", Wear, v. 271, n. 9, pp. 2512-2516, Jul. 2011.

[8] KOVÁCS, J.G., SIKLO, B., "Test method development for deformation analysis of injection moulded plastic parts”, Polymer Testing, v. 30, n. 5, pp. 543-547, Aug. 2011.

[9] CHEN, C., WANG, Y., OU, H., et al., "A review on remanufacture of dies and moulds", Journal of Cleaner Production, v. 64, pp. 13-23, Feb. 2014.

[10] LEE, J.C., KANG, H.J., CHU, W.S., et al., "Repair of damaged mold surface by cold-spray method”, In: CIRP Annals-Manufacturing Technology, pp. 577-580, 2007.

[11] JHAVAR, S., PAUL, C.P., JAIN, N.K., “Causes of failure and repairing options for dies and molds: A review”, Engineering Failure Analysis, v. 34, pp. 519-535, Dec. 2013.

[12] KOŠNIK, A., TUŠEK, J., KOSEC, L., et al., "The manufacturing of a two-layered injection mold by welding", Metalurgija, v. 50, n. 4, 2011.

[13] Hill, M., Carlson, J., MOLDMAKING TECHNOLOGY, https://www.moldmakingtechnology.com/articles/transition-to-in-house-welding-. Accessed 15 October 2017.

[14] CHEN, C., WANG, Y., OU, H., "Study of weld characteristics for repair using sequential experimental design and artificial neural network", International Journal of Advanced Manufacturing Technology, v. 84, n.5-8, pp. 1313-1323, 2016.

[15] Welding, Brazing and Soldering, v. 6, Ohio, ASM Metals Handbook, 1993.

[16] CAPELLO, E., PREVITALI, B., "The influence of operator skills, process parameters and materials on clad shape in repair using laser cladding by wire”, Journal of Materials Processing Technology, v. 174, n. 1, pp. 223-232, May 2006.

[17] PRECIADO, W.T., BOHORQUEZ, C.E.N., "Repair welding of polymer injection molds manufactured in AISI P20 and VP50IM steels", Journal of Materials Processing Technology, v. 179, n. 1, pp. 244-250, Oct. 2006.

[18] OLIANI, W.L., PARRA, D.F., LIMA, L.F.C.P., et al., "Morphological characterization of branched PP under stretching”, Polymer Bulletin, v. 68, pp. 2121-2130, May 2012.

[19] VEDANI, M., PREVITALI, B., VIMERCATI, G.M., et al., "Problems in laser repair-welding a surface-treated tool steel”, Surface and Coatings Technology, v. 201, n. 8, pp. 4518-4525, Jan. 2007.

[20] VEDANI, M.,"Microstructural evolution of tool steels after Nd-YAG laser repair welding”, Journal of Materials Science, v. 39, n. 1, pp. 241-249, Jan. 2004.

[21] SILVA, B., PIRES, I., QUINTINO, L., et al., "New welding procedures for repairing H13 and P20 tool steels", In: $5^{\text {th }}$ 
Luso-Mozambican International Engineering Congress, 2008.

[22] COSTA, J.M., PIRES, J.T.B., ANTUNES, F., et al., "Residual stresses analysis of ND-YAG laser welded joints", Engineering Failure Analysis, v. 17, n. 1, pp. 28-37, Jan. 2010.

[23] BORREGO, L.P., PIRES, J.T.B., COSTA, J.M., et al., "Mould steels repaired by laser welding”, Engineering Failure Analysis, v. 16, n. 2, pp. 596-607, Mar. 2009.

[24] JHAVAR, S., JAIN, N.K., PAUL, C.P., "Development of micro-plasma transferred arc ( $\mu$-PTA) wire deposition process for additive layer manufacturing applications", Journal of Materials Processing Technology, v. 214, n. 5, pp. 11021110, May 2014.

[25] WANDER, P.R., COSTA, C.A., SCAIN, F., "Um estudo comparativo de sistemas de resfriamento em moldes para injeção de produtos aletados", $8^{\text {th }}$ Ibero-American Mechanical Engineering Congress, Cusco, Mexico, 24-26 September 2007.

[26] TREML JUNIOR, C.A., LEITE, J.L., SOUSA, A.F., et al., 2012, "Morphological characterization of injection molded parts in Ren Shape 5166 polyurethane inserts for rapid tooling". In: PMI 2012-International Conference on Polymers and Moulds Innovations, pp. 201-206.

[27] ČERMÁK, R., OBADAL, M., PONÍŽIL, P., et al., "Injection-moulded $\alpha$-and $\beta$-polypropylenes: I. Structure vs. processing parameters”, European Polymer Journal, v. 41, n. 8, pp. 1838-1845, 2005.

[28] MARTINHO, P.G., BÁRTOLO, P.J., POUZADA, A.S., "Hybrid moulds: effect of the moulding blocks on the morphology and dimensional properties", Rapid Prototypes J, v. 15, n. 1, pp. 71-82, 2009.

[29] BARETA, D.R., COSTA, C.A., ZATTERA, A.J., et al., "Influência de materiais alternativos nas propriedades de peças tubulares no contexto de moldes protótipos de injeção (Influence of alternative materials on the properties of tubular parts of injection molds prototypes)", Tecnologia em Metalurgia, Materiais e Mineração, v. 4, n. 3, pp. 37-42, 2008.

[30] RIZVI, S.J.A., SINGH, A.K., BHADU, G.R., "Optimization of tensile properties of injection molded $\alpha$-nucleated polypropylene using response surface methodology”. Polymer Testing, doi: 10.1016/j.polymertesting.2017.03.021. 2017.

[31] JIANG, J., WANG, S., SUN, B., MA, S., ZHANG, J., LI, Q., HU, GUO-HUA, "Effect of mold temperature on the structures and mechanical properties of micro-injection molded polypropylene". Materials and Design, v. 88 pp. 245-25, 2015.

[32] DAWSON, A., RIDES, M., ALLEN, C.R.G., URQUHART, J.M. "Polymer-mould interface heat transfer coefficient measurements for polymer”. Polymer Testing, v.27, pp. 555-565, 2008.

[33] ROSATO, D.V., Plastics Encyclopedia and Dictionary, 1st ed., New York, Hanser, 1993.

\section{ORCID}

Rafael Junkes

Daniela Becker

Janaina Lisi Leite Howarth

Danielle Bond https://orcid.org/0000-0003-4812-2341

https://orcid.org/ 0000-0003-3250-576X

https://orcid.org/ 0000-0003-3991-9295

https://orcid.org/ 0000-0002-0489-5812 